\title{
Lipogenesis in arterial wall and vascular smooth muscular cells:
} regulation and abnormalities in insulin-resistance

\author{
Nadjiba Hamlat ${ }^{1}$, Fabien Forcheron ${ }^{1}$, Samia Negazzi ${ }^{2}$, Peggy del Carmine ${ }^{3}$, \\ Patrick Feugier $^{1,4}$, Giampiero Bricca ${ }^{1}$, Souhila Aouichat-Bouguerra ${ }^{2}$ and \\ Michel Beylot*1,3
}

\author{
Address: ${ }^{1 E R I-22}$ - EA4173, Faculté Rockefeller, UCBLyon1, Lyon, France, ${ }^{2}$ USTB H Boumedienne, Alger, Algérie, ${ }^{3}$ ANIPHY, Faculté Rockefeller, \\ UCBLyon1, Lyon, France and ${ }^{4}$ Hospices Civils de Lyon, Lyon, France \\ Email: Nadjiba Hamlat - nadjiba.hamlat@gmail.com; Fabien Forcheron - fforcheron@yahoo.fr; Samia Negazzi - neggazi-samia@caramail.com; \\ Peggy del Carmine - PEGGY.DEL-CARMINE@recherche.univ-lyon1.fr; Patrick Feugier - patrick.feugier@wanadoo.fr; \\ Giampiero Bricca - giampiero.bricca@inserm.fr; Souhila Aouichat-Bouguerra - souhila.aouichat@hotmail.fr; \\ Michel Beylot* - beylot@sante.univ-lyon1.fr \\ * Corresponding author
}

Published: 23 December 2009

Cardiovascular Diabetology 2009, 8:64 doi:10.1 186/1475-2840-8-64

This article is available from: http://www.cardiab.com/content/8///64

(c) 2009 Hamlat et al; licensee BioMed Central Ltd.

This is an Open Access article distributed under the terms of the Creative Commons Attribution License (http://creativecommons.org/licenses/by/2.0), which permits unrestricted use, distribution, and reproduction in any medium, provided the original work is properly cited.
Received: 3 November 2009

Accepted: 23 December 2009

\begin{abstract}
Background: Vascular smooth muscular cells (VSMC) express lipogenic genes. Therefore in situ lipogenesis could provide fatty acids for triglycerides synthesis and cholesterol esterification and contribute to lipid accumulation in arterial wall with aging and during atheroma.
\end{abstract}

Methods: We investigated expression of lipogenic genes in human and rat arterial walls, its regulation in cultured VSMC and determined if it is modified during insulin-resistance and diabetes, situations with increased risk for atheroma.

Results: Zucker obese (ZO) and diabetic (ZDF) rats accumulated more triglycerides in their aortas than their respective control rats, and this triglycerides content increased with age in ZDF and control rats. However the expression in aortas of lipogenic genes, or of genes involved in fatty acids uptake, was not higher in ZDF and ZO rats and did not increase with age. Expression of lipogenesis-related genes was not increased in human arterial wall (carotid endarterectomy) of diabetic compared to non-diabetic patients. In vitro, glucose and adipogenic medium (ADM) stimulated moderately the expression and activity of lipogenesis in VSMC from control rats. LXR agonists, but not PXR agonist, stimulated also lipogenesis in VSMC but not in arterial wall in vivo. Lipogenic genes expression was lower in VSMC from ZO rats and not stimulated by glucose or ADM.

Conclusion: Lipogenic genes are expressed in arterial wall and VSMC; this expression is stimulated (VSMC) by glucose, ADM and LXR agonists. During insulin-resistance and diabetes, this expression is not increased and resists to the actions of glucose and ADM. It is unlikely that this metabolic pathway contribute to lipid accumulation of arterial wall during insulin-resistance and diabetes and thus to the increased risk of atheroma observed in these situations. 


\section{Introduction}

Excessive accumulation of lipid substrates in non-adipose tissues has serious adverse effects on cell functions (lipotoxicity) [1] and can contribute to the development of insulin-resistance [2]. Indeed numerous studies have shown an inverse relationship between tissue lipid accumulation and sensitivity to insulin of glucose metabolism in liver [3] and skeletal muscle [4]. In such studies tissue lipid accumulation is usually appreciated by measuring triglycerides (TG) content although recent studies clearly show that deleterious effects are not due to the accumulation of TG itself [5] but to other lipid metabolites such as palmitate, diacylglycerols and ceramide [6-8]. The arterial wall of obese Zucker rats is insulin-resistant although this resistance is limited to the PI3-kinase pathway [9]. In addition, this pathway has also been found insulin-resistant in cultured vascular smooth muscular cells (VSMC) of diabetic patients [10]. The mechanisms responsible for this resistance have not been clarified. It could result from excessive concentration of plasma cytokines such as TNF $\alpha$ [11], of raised levels of angiotensin II or local overexpression of components of the renin-angiotensin system $[10,12]$. It could also result of excessive accumulation of lipid substrates. Actually, arterial wall accumulate TG with aging [13]. In addition, foam cells of atheroma plaques accumulate not only cholesterol but also significant amounts of TG (8-10\%of total lipid) [14-16]. These cellular TG modify the physical state of stored esterified cholesterol and this could affect the way it is hydrolyzed and effluxed [17]. Therefore, accumulation of TG could also play a role in atheroma. TG synthesis, as well as cholesterol esterification, requires long chain fatty acyl-CoA. Acyl-CoA can be provided by the uptake of circulating lipids (plasma non esterified fatty acids, NEFA, or TG-fatty acids of TG rich lipoproteins) but also by in situ synthesis, the pathway of de novo lipogenesis (DNL). Indeed, arterial wall, foam cells, macrophages and vascular smooth muscular cells (VSMC) incorporate labeled acetate into phospholipids and TG [18]. More recently, Davies et al [13] showed that human VSMC express lipogenic genes such as Srebp-1c, the transcription factor mediating the lipogenic action of insulin [19], and fatty acid synthase (FAS) and that these expressions, and the intracellular accumulation of TG, are increased by culture in an adipogenic differentiation medium (ADM). Moreover, TO901317, a LXR agonist, also stimulated the expression of Srebp-1c and FAS suggesting that the lipogenic action of LXR described in liver, adipose tissue and skeletal muscle [20-23] is also present in VSMC. Lastly Davies et al found that FAS and Srebp-1c are expressed in human atherosclerotic lesions and suggested that enhanced VSMC lipogenesis and lipid accumulation could be involved in the development of atheroma [13]. This possibility should be kept in mind when developing nuclear receptor agonists for treatment of atherosclerosis.
Insulin-resistance and type 2 diabetes are risk factors for atherosclerosis and are characterized by high concentrations of insulin and/or glucose. Lipogenesis is stimulated in tissues such as liver by insulin and glucose $[19,24,25]$. If present in arterial wall, this stimulation could result in increased tissue lipid accumulation, aggravating further the resistance to insulin of local glucose metabolism, and possibly contribute to the accelerated atherosclerosis of insulin-resistance and diabetes. However, the expression of lipogenic genes is not increased but rather decreased in skeletal muscle of insulin-resistant and type 2 diabetic subjects, and is resistant to the action of insulin [26]. Therefore, our aims were to determine i) if TG accumulation is increased in arterial wall in experimental models of insulin-resistance and diabetes and if an increased expression of lipogenesis-related genes could contribute to this increase, ii) if lipogenesis is stimulated by insulin and glucose in VSMC and if this response is modified by insulinresistance. In addition, we determined whether lipogenesis in VSMC is responsive or not to other hormones (thyroid hormones, angiotensin II) known to stimulate it in other cells such as hepatocytes or adipocytes. Lastly, the LXR agonist (TO90137) used by Davies et al has been shown to be actually a dual, LXR and PXR agonist [27]. PXR stimulates lipogenesis in liver [28] and is expressed in the vasculature [29]. Therefore we verified whether the effects of TO901317 in VSMC were mediated by activation of LXR or of PXR.

\section{Materials and methods In vivo studies in rats}

These studies were conducted in accordance with the French regulation for experimentation in animals. Male Zucker obese $(\mathrm{ZO}, \mathrm{n}=18)$ and Zucker diabetic $(\mathrm{ZDF}, \mathrm{n}=$ $15)(\mathrm{fa} / \mathrm{fa})$ rats and their control, normal littermates (controls $\mathrm{CO}, \mathrm{n}=18$, and $\mathrm{CZ}, \mathrm{n}=15$, respectively, $+/+$ ) (Charles River, L'Arbresle, France) were housed at arrival (six weeks old) in an animal facility with controlled temperature $\left(22 \pm 1^{\circ} \mathrm{C}\right)$ and lightning (light on at 7:00 AM and off at 7:00 PM). Throughout the study they had free access to water and food. All ZDF rats and their controls received the diet (Purina 5008, protein 26.8\%, carbohydrate $56.4 \%$ (91\% starch, 9\% simples carbohydrates), fat $16.7 \%$ of caloric value, IPS, London, UK) recommended for the development of diabetes in male ZDF rats. ZO rats and their controls received standard diet. Body weight was recorded once a week. After one week of acclimatizing (age of 7 weeks) five rats of the ZDF and $\mathrm{CZ}$ groups and six of the $\mathrm{ZO}$ and $\mathrm{CO}$ groups were sacrificed for blood collection and tissue sampling. The remaining rats were sacrificed at the age of 14 weeks or of 21 weeks ( 5 rats of the ZDF and CZ groups and 6 rats of the $\mathrm{ZO}$ and $\mathrm{CO}$ groups at each sacrifice) 
The day of sacrifice, food was removed at 08:00 AM and rats anesthetized at 02:00 PM (pentobarbital IP $60 \mathrm{mg} /$ $\mathrm{kg})$, in the post-absorptive state. Blood was collected and plasma stored at $-20^{\circ} \mathrm{C}$ until analysis. Thoracic aorta was removed, flushed with cold isotonic saline, carefully cleaned of perivascular adipose tissue and flash frozen in liquid nitrogen before storage at $-80^{\circ} \mathrm{C}$ until analysis. Liver samples were also collected from $\mathrm{ZO}$ and $\mathrm{CO}$ rats, washed with cold isotonic saline, flash frozen with liquid nitrogen and stored at $-80^{\circ} \mathrm{C}$ until analysis

\section{Carotid endarterectomy in human subjects}

The procedure was approved by local ethical committee and all subjects gave their informed consent. Human atheroma plaques were removed during carotid endarterectomy from 12 subjects ( 8 males, 4 females, aged $65 \pm 5$ years). 6 subjects had overt type 2 diabetes with mild glucose control (plasma glucose: $8.91 \pm 1.90 \mathrm{mM}$ ). The others had evidence of insulin resistance with normal plasma glucose $(4.66 \pm 0.30 \mathrm{mM})$ and moderate increase in basal level of plasma insulin concentration $(16.8 \pm 1.7 \mathrm{mU} / \mathrm{L}$, normal $<10 \mathrm{mU} / \mathrm{L}) .3$ diabetic subjects received metformin and 3 sulfonylurea treatment. Diabetic and nondiabetic patients had comparable BMI $(26.7 \pm 2.0$ vs 26.5 \pm 1.8 ) but diabetic subjects had higher plasma cholesterol $(5.46 \pm 0.16$ vs $4.40 \pm 0.41 \mathrm{mM} \mathrm{p}<0.05)$ and TG $(2.28 \pm$ 0.19 vs $1.51 \pm 0.11 \mathrm{mM}$ p $<0.01$ ) levels. Samples collected directly in the surgery room were immediately divided in 2 parts, atheroma plaque and macroscopically intact tissue (MIT) situated in the vicinity of the plaque, and were flash frozen in liquid nitrogen [30].

\section{In vitro studies}

Vascular smooth muscle cells culture

Explants were obtained from thoracic aorta [30] of ZO and CO rats (14 weeks old); they were prepared after removing adventitia by collagenase action $(0.1 \%$, type IA, Sigma, L'Isle d'Abeau, France). Small fragments were prepared and placed in $25 \mathrm{~cm}^{2}$ culture dishes in VSMC culture medium (Promocell, Heidelberg, Germany) and maintained at $37^{\circ} \mathrm{C}$ under air- $\mathrm{CO}_{2}$ (95\%-5\%) atmosphere until they reached confluence. Then, VSMC were trypsinized (0.08\% of trypsin; Gibco, USA) and subcultured. For the experiments, $10^{6} \mathrm{VSMC} / \mathrm{ml} /$ well were seeded in 6 well plates in their usual medium for at least two days. Twenty four hours before starting the experiments, culture medium was replaced by a basal VSMC medium without fetal calf serum. On the first day of the experiments cells were collected in two wells (duplicate) for basal values (D0); culture medium was replaced in other wells and the test substances were added at appropriate concentrations. All experiments were done with cells at passage 3 to 5 or earlier.
Effects of glucose and adipogenic differentiation factors (ADM)

Cells were cultured for 3, 7 or 21 days [13] in the presence of basal ( $1 \mathrm{~g} / \mathrm{l})$ or high $(5 \mathrm{~g} / \mathrm{l})$ glucose concentration and in the presence or absence of ADM (insulin $1.2 \mu \mathrm{M}$, dexamethasone $100 \mathrm{nM}$, tritiodothyronine (T3) $1 \mathrm{nM}$ and 3 isobutyl-1-methyl xanthine (IBMX) $0.25 \mathrm{mM}$, final concentrations in culture medium). This adipogenic differentiation medium is identical to the one shown by Davies et al to stimulate the expression of lipogenic genes in human VSMC [13]. Cells remained viable throughout the experiments. We tested also the effects of the addition (during 3 days and 7 days) of insulin or T3 alone (same final concentrations). Lastly, since components of the renin-angiotensin system are expressed in arterial wall and VSMC [10] and angiotensin II (AngII) stimulates adipocyte differentiation as well as FAS expression and lipogenesis in adipose cells and liver [31,32], we also tested the effects of AngII (100 nM) on the expression of lipogenic genes. In order to determine if modifications of the expression of lipogenic genes is accompanied by parallel modifications of the activity of the lipogenic pathway we measured in most experiments this activity by determining the incorporation of deuterium from deuterated water into the palmitate of cellular TG [28]. In short deuterated water (30 $\mu \mathrm{l} / \mathrm{ml}$ of culture medium) was added $24 \mathrm{~h}$ before the end of experiments. 24 h later culture medium and VSMC were collected for measures of deuterium enrichment.

\section{Effects of $L X R$ and $P X R$ agonists}

The dual LXR and PXR agonist TO901317 was from Calbiochem (Merck, Darmstadt, Germany), others, specific, LXR agonists (GW3965, paxillin [27,28,33]) and the PXR agonist (Pregnen-3B-OL-20-ONE-16A-Carbonitrile, PCN) were from Sigma. Compounds were dissolved in ethanol (10-30 mM stock solution) and used at the final concentrations of $10 \mu \mathrm{M}$ (TO901317 and paxillin) and 30 $\mu \mathrm{M}$ (PCN). Cells obtained from aortas of $\mathrm{CO}$ rats were cultured in the absence (control) or presence of one of the agonists during three days. Ethanol was added in the control culture at the same final concentration than in the test cultures. GW3965 was given by oral gavage to mice (40 $\mathrm{mg} / \mathrm{kg}$ in $0.5 \%$ methylcellulose once a day during three days, $n=12)$. Control mice $(n=12)$ received only methylcellulose. Thereafter plasma was sampled and mice were sacrificed for collection of liver and aortas. Six aortas from each group were used for determination of TG content and six for mRNA measurements.

\section{Determinations}

Blood glucose levels were measured with a glucometer (One Touch Ultra, Life technology, Issy-Les-Moulineaux, France), plasma and tissues TG by enzymatic methods [34] and insulin by ELISA (Cristal Chem, Downers Grove, Il, USA). For measurement of aortic TG concentrations, parts of the aortas were homogenized in chloroform/ 
methanol $(1: 2, \mathrm{v}: \mathrm{v})$. The chloroform phase was collected, washed with water and dried under nitrogen. Extracted lipids were dissolved in propanol for enzymatic determination of TG concentration [35]. The same procedure was used for determination of TG concentrations in VSMC. Measurements of deuterium enrichments in the palmitate of VSMC TG were performed as previously described $[28,36,37]$ as well as the calculation of the contribution of lipogenesis to the cellular TG pool [34,38].

Liver, aortas, endarterectomy pieces or VSMC total RNAs were purified using TRIZOL ${ }^{\mathrm{R}}$ protocol (Invitrogen, CergyPontoise, France) with the addition of a DNase treatment. Concentrations and purity were verified by measuring optical density at 230, 260 and $280 \mathrm{~nm}$ and integrity by agarose gel electrophoresis. For measurements of individual mRNA levels, total RNA was reverse transcripted using Superscript II (Invitrogen) and random hexamers. Real time PCR was performed in a MyIQ thermal cycler (Biorad, Marnes La Coquette, France) using iQ SYBR green Supermix (Biorad). All samples were run in duplicate along with dilutions of known amounts of target sequence for quantification of initial cDNA copies. Results are expressed as the target over 18S RNA concentration ratio $(\mathrm{ng} / \mu \mathrm{g})$. Primer sequences are shown in table 1.

\section{Statistics}

Results are shown as mean \pm sem. For in vivo rat studies comparisons were performed by two-way ANOVA (factors: time and genotype) followed by Bonferroni test. BMI and plasma values of diabetic and non-diabetic subjects were compared by two tailed t test for unpaired values and mRNA values were compared by two-way ANOVA (diabetic or not, atheroma plaque or MIT) followed by Bonferroni test. For in vitro studies, comparisons of data obtained from VSMC of $\mathrm{ZO}$ and $\mathrm{CO}$ rats in the initial (basal) state and after culture without or with high glucose concentration and/or ADM were performed by twotailed Student $\mathrm{t}$ test for unpaired values. Data obtained in the absence or presence of insulin, T3, AngII, of one of the LXR or PXR agonists, were compared by one way ANOVA followed by the Dunnett test to locate the differences. Values obtained in mice having received GW3965 or vehicle alone were compared by two-tailed Student t test for unpaired values. $\mathrm{P}<0.05$ was considered as indicating a significant difference. Calculations were performed with GraphPad Prism 4.02 (GraphPad, San Diego, CA, USA).

\section{Results}

I. Hormone and metabolites values in rats (Tables 2 and 3) 7 week old ZDF rats had normal glucose concentrations but high insulin levels $(\mathrm{p}<0.01)$ indicating the presence of insulin-resistance (table 2). They had overt diabetes at the age of 14 and 21 weeks, with persistence of some insu- lin secretion at 14 weeks, but almost undetectable insulin level at 21 weeks. Plasma TG concentrations were very high in ZDF rats ( $\mathrm{p}<0.001$ vs CZ group). TG concentrations in aortas (table 3 ) increased with age in both CZ and ZDF rats, with values higher in both groups at 21 than at 7 week $(\mathrm{p}<0.05)$. These concentrations were higher in ZDF rats at 7 and 14 week $(\mathrm{p}<0.01)$ with a trend for higher values at 21 weeks.

$\mathrm{ZO}$ rats were insulin-resistant at 7 and 14 weeks, with normal glucose but raised insulin levels, and developed mild type 2 diabetes at 21 weeks (table 2). Their plasma TG concentrations increased with age and were always higher than in CO rats. TG concentrations in aortas were higher in $\mathrm{ZO}$ and $\mathrm{CO}$ rats than in $\mathrm{ZDF}$ and the $\mathrm{CZ}$ rats respectively. There was a non significant trend for higher values with increasing age in both $\mathrm{ZO}$ and $\mathrm{CO}$ rats and concentrations were higher in $\mathrm{ZO}$ than in the corresponding control group at 14 weeks with a non-significant trend at 7 and 21 weeks (table 3 ).

\section{Expression in arterial wall of genes involved in de novo lipogenesis and in plasma lipids uptake (figures I and 2)}

We next measured in aortas of ZDF (figure 1) and ZO rats (figure 2) and of their corresponding controls the mRNA levels for key enzymes of DNL (ACC1, FAS) and for transcription factors mediating the stimulatory effects of insulin (Srebp-1c) and glucose (ChREBP) on the expression of lipogenic genes. The expression of these genes did not increase with age in both ZDF and ZO rats, as well as in their respective controls. Moreover mRNA levels were not increased either in ZDF or in $\mathrm{ZO}$ rats. Concentrations were comparable to those found in control rats or slightly decreased as for Srebp-1c. Therefore there was no correlation between the expression of lipogenic genes and TG content in aortas and no evidence for an overexpression in aorta of the lipogenic pathway in these models of insulinresistance and diabetes. This lack of increased expression of lipogenic genes in aortas contrast with the increase found in liver of $\mathrm{ZO}$ rats (figure 3) and previously reported in livers of $Z D F$ rats $[35,39,40]$. In the present experiments, the expression of genes involved in the uptake of plasma NEFA (FAT) or of fatty acids from TG rich lipoproteins (LPL and VLDLr) also did not increase with age and was not higher in aortas from ZDF and ZO rats than from their controls. Taken all together these results suggest that the increased TG content of aorta in $\mathrm{ZO}$ and ZDF rats does not result from an increased expression of pathways for fatty acids synthesis or uptake but probably merely of an increased availability for uptake of plasma lipid substrates.

Lastly we measured the expression of lipogenic genes in human arterial wall by measuring relevant mRNA levels in atheroma plaques and nearby macroscopically intact tis- 
Table I: Primers used for the determination by real-time PCR of mRNA concentrations:

\begin{tabular}{|c|c|c|c|}
\hline Name & Forward primer & Reverse primer & Size (bp) \\
\hline \multicolumn{4}{|l|}{ In rats } \\
\hline $\mathrm{ACCl}$ & caacgcaggcatcagaa & caagtattccacagtccc & 138 \\
\hline ChREBP & cgggacatgtttgatgactatgtc & aataaaggtcggatgaggatgct & 86 \\
\hline FAS & ggtgctacccattcgtg & ggatgtatcattcttggactt & 115 \\
\hline Srebp-Ic & cgctaccgttcctctatcaa & ttcgcagggtcaggttctcc & 164 \\
\hline VLDLr & tctggagttcctagctcat & ccagtgaatttattggcacc & 108 \\
\hline FAT & aggaagtggcaaagaat & tgaaggctcaaagatgg & 155 \\
\hline LPL & cctgaagacacagctgagga & cacccaactctcatacattc & $|4|$ \\
\hline \multicolumn{4}{|l|}{ In mice: } \\
\hline $\mathrm{ACCl}$ & cgctggtcttagaagttga & tccctgcygatgtatttgat & 149 \\
\hline ChREBP & gtccgatatctcgacacactc & cattgccaacataagcatgttctg & 91 \\
\hline FAS & tgctgccgtgtccttctacca & gcacccaagtcctcgccata & 128 \\
\hline Srebp-Ic & ggcactaagtgccctcaacct & gccacatagatctctctgccagtgt & 81 \\
\hline FATP & cctgcggcttcaaca & tcagtggctccatcgt & 84 \\
\hline FAT & ggaactgtgggctcattgc & catgagaatgcctccaaacac & 68 \\
\hline \multicolumn{4}{|l|}{ In humans } \\
\hline $\mathrm{ACCl}$ & acatccctacgctaaaca & agaacatcgctgacacta & 85 \\
\hline ChREBP & tcggcaatgctgacatg & gaggcgggagttggtaaa & 98 \\
\hline FAS & acggccctcatttccag & tgaagctcacccagttatcc & 87 \\
\hline Srebp-Ic & tgaagacagacggagcca & ggactgttgccaagatggtt & 120 \\
\hline I8S (mice, Rat, human) & tgaggccatgattaagaggg & agtcggcatcgtttatggtc & 190 \\
\hline
\end{tabular}

sue (MIT) collected during endarterectomy in diabetic and non diabetic subjects with carotid atheroma (figure 4). In MIT, expressions of FAS, ACC1, Srebp-1c and ChREBP were not increased but rather decreased in diabetic subjects. In non-diabetic subjects there was no difference in mRNA concentrations between MIT and atheroma whereas in diabetic patients there was in plaques a clear trend for higher values with concentrations, for ACC1, Srebp-1c and ChREBP near to those observed in plaques of non-diabetic subjects. These variations could merely reflect differences in cell population, but there is clearly in diabetic humans compared to non-diabetic subjects no increased expression of lipogenesis in arterial wall, as in diabetic rats.

\section{Expression in cultured VSMC of genes involved in DNL and in lipids uptake}

We next investigated the expression of lipogenic genes in cultured VSMC obtained from aortas of Zucker obese and control rats. mRNA concentrations of ACC1, FAS, Srebp$1 \mathrm{c}$ and ChREBP were measured in basal conditions (DMEM with $5 \mathrm{mM}$ glucose) (D0) and then during 3, 7 
Table 2: Plasma values in Zucker obese (ZO) and Zucker diabetic (ZDF) rats and in their respective controls (CO and CZ).

\begin{tabular}{|c|c|c|c|c|}
\hline & $\mathbf{C Z}$ & ZDF & CO & ZO \\
\hline \multicolumn{5}{|c|}{ Triglycerides mM } \\
\hline 7 weeks & $0.53 \pm 0.06$ & $4.12 \pm 0.48^{* * *}$ & $0.49 \pm 0.09$ & $1.19 \pm 0.09 * *$ \\
\hline 14 weeks & $0.54 \pm 0.07$ & $3.78 \pm 0.39 * * * *$ & $0.55 \pm 0.07$ & $2.15 \pm 0.30 * *$ \\
\hline 21 weeks & $0.59 \pm 0.05$ & $5.85 \pm 1.03^{* * * *}$ & $0.72 \pm 0.17$ & $3.73 \pm 1.09 * \$$ \\
\hline \multicolumn{5}{|c|}{ Glucose mM } \\
\hline 7 weeks & $7.39 \pm 0.28$ & $7.32 \pm 0.31$ & $6.89 \pm 0.13$ & $7.56 \pm 0.53$ \\
\hline 14 weeks & $7.02 \pm 0.39$ & $30.11 \pm 0.91$ *** & $7.52 \pm 0.58$ & $7.90 \pm 0.34$ \\
\hline 21 weeks & $7.58 \pm 0.32$ & $30.20 \pm 0.21^{* * *}$ & $6.05 \pm 0.64$ & $10.59 \pm 2.45^{*} \$$ \\
\hline \multicolumn{5}{|l|}{ Insulin $\mu g / L$} \\
\hline 7 weeks & $4.7 \pm 0.7$ & $16.0 \pm 3.0 * *$ & $0.8 \pm 0.4$ & $4.8 \pm 1.0 * * *$ \\
\hline I4 weeks & $6.8 \pm 1.1$ & $4.5 \pm 1.0$ & $1.7 \pm 0.4$ & $6.7 \pm 0.3 * * *$ \\
\hline 21 weeks & $8.5 \pm 0.5$ & $<0.05^{* *}$ & $1.2 \pm 0.2$ & $6.3 \pm 0.5^{* * *}$ \\
\hline
\end{tabular}

Measurements were made in the post-absorptive state.

${ }^{*} \mathrm{p}<0.05$, ** $\mathrm{p}<0.01$, *** $\mathrm{p}<0.001$ vs the respective control group; $\$ \mathrm{p}<0.05$ vs the value at 7 weeks of the same group

and 21 days (D3, D7, D21) of culture in presence of high glucose concentrations $(25 \mathrm{mM})$ and/or adipogenic medium (ADM) compared with 3, 7 and 21 days of culture in basal conditions ( $5 \mathrm{mM}$ glucose, no ADM). In the initial state (D0, DMEM $5 \mathrm{mM}$ glucose) there was a trend for higher Srebp-1c mRNA concentration in VSMC of Zucker obese rats, whereas mRNA concentrations of ChREBP and ACC1 were comparable and those of FAS decreased $(p<0.05)$ in cells from Zucker obese rats (figure $5)$. When culture was continued in basal conditions (DMEM, $5 \mathrm{mM}$ glucose) there was a progressive decline of all mRNA concentrations in VSMC of both control and obese rats (figure 6 and 7). This fall in mRNA values was for Srebp-1c, ChREBP and FAS more important in cells of obese rats and at 21 days, all these values were lower in cells from obese than from control rats (figure 6 and 7). The addition of high glucose concentration or of adipogenic medium opposed in part the decline of Srebp-1c and ChREBP mRNA concentrations in VSMC of control rats, but without significant modifications in the evolution of ACC1 and FAS mRNA values. Neither high glucose concentration nor adipogenic medium modified the evolution of mRNA values in cells from Zucker obese rats, and values attained at 21 days were always lower than in cells from control rats. In addition, ADM increased largely at 21 days TG content $\left(233 \pm 22 \mathrm{vs} 114 \pm 11 \mu \mathrm{g} / 10^{6}\right.$ cells, $\mathrm{p}<0.001)$ and the contribution of DNL to this TG pool $\left(12.1 \pm 1.9\right.$ vs $7.1 \pm 0.5 \mu \mathrm{g} / 10^{6}$ cells, $\left.\mathrm{p}<0.05\right)$ in VSMC from control rats whereas the increases were only moderate in cells of obese rats $\left(170 \pm 11 \mathrm{vs} 129 \pm 17 \mu \mathrm{g} / 10^{6}\right.$ cells, $\mathrm{p}<0.05$ and $10.1 \pm 0.9$ vs $6.6 \pm 1.3 \mu \mathrm{g} / 10^{6}$ cells $\mathrm{p}<0.05$, respectively) (figure 8). Insulin or T3 alone increased moderately FAS mRNA, always only in cells from control rats (figure 9), but not other lipogenic mRNA concentrations (data not shown). In addition, neither the cell content of TG nor the activity of the lipogenic pathway measured with deuterated water were modified by insulin or T3 in cells from control or obese rats (figure 8). AngII had a marked effect on FAS expression in VSMC of control rats and a moderate action in cells from obese rats (figure $9)$. However other lipogenic mRNAs were not significantly modified by AngII and cellular TG content as well as activity of lipogenesis (figure 8) were unchanged.

Davies et al reported that TO901317 stimulated the expression of lipogenic genes in VSMC and ascribed it to a stimulation of LXR $\alpha$ [13]. However TO901317 is a dual LXR and PXR agonist [27]. PXR stimulates lipogenesis in liver [28], is expressed in vasculature [29] and we found that it is expressed at least at the mRNA level in VSMC (data not shown). Therefore we compared the effects of TO901317 with those of paxillin (LXR agonist $[28,33]$ ) and of PCN (PXR agonist) on VSMC of control rats. Three days of culture with TO901317 increased largely TG con-

Table 3: TG content in aortas of Zucker obese (ZO) and diabetic (ZDF) rats and in their respective controls (Co and CZ).

\begin{tabular}{lllll}
\hline TG $\mu$ g/mg tissue & CZ & ZDF & CO & ZO \\
\hline 7 weeks & $0.28 \pm 0.06$ & $2.10 \pm 0.42^{* *}$ & $27.8 \pm 5.8$ & $49.1 \pm 5.3^{*}$ \\
14 weeks & $0.50 \pm 0.09$ & $2.57 \pm 0.37^{* *}$ & $26.4 \pm 4.2$ & $66.9 \pm 7.8^{* *}$ \\
21 weeks & $2.64 \pm 1.16 \$$ & $4.92 \pm 1.37 \$$ & $46.6 \pm 11.2$ & $66.6 \pm 7.2$ \\
\hline
\end{tabular}

$*_{\mathrm{p}}<0.05,{ }^{*} \mathrm{p}<0.01$ vs the respective control group; $\$ \mathrm{p}<0.05$ vs the value at 7 weeks of the same group 

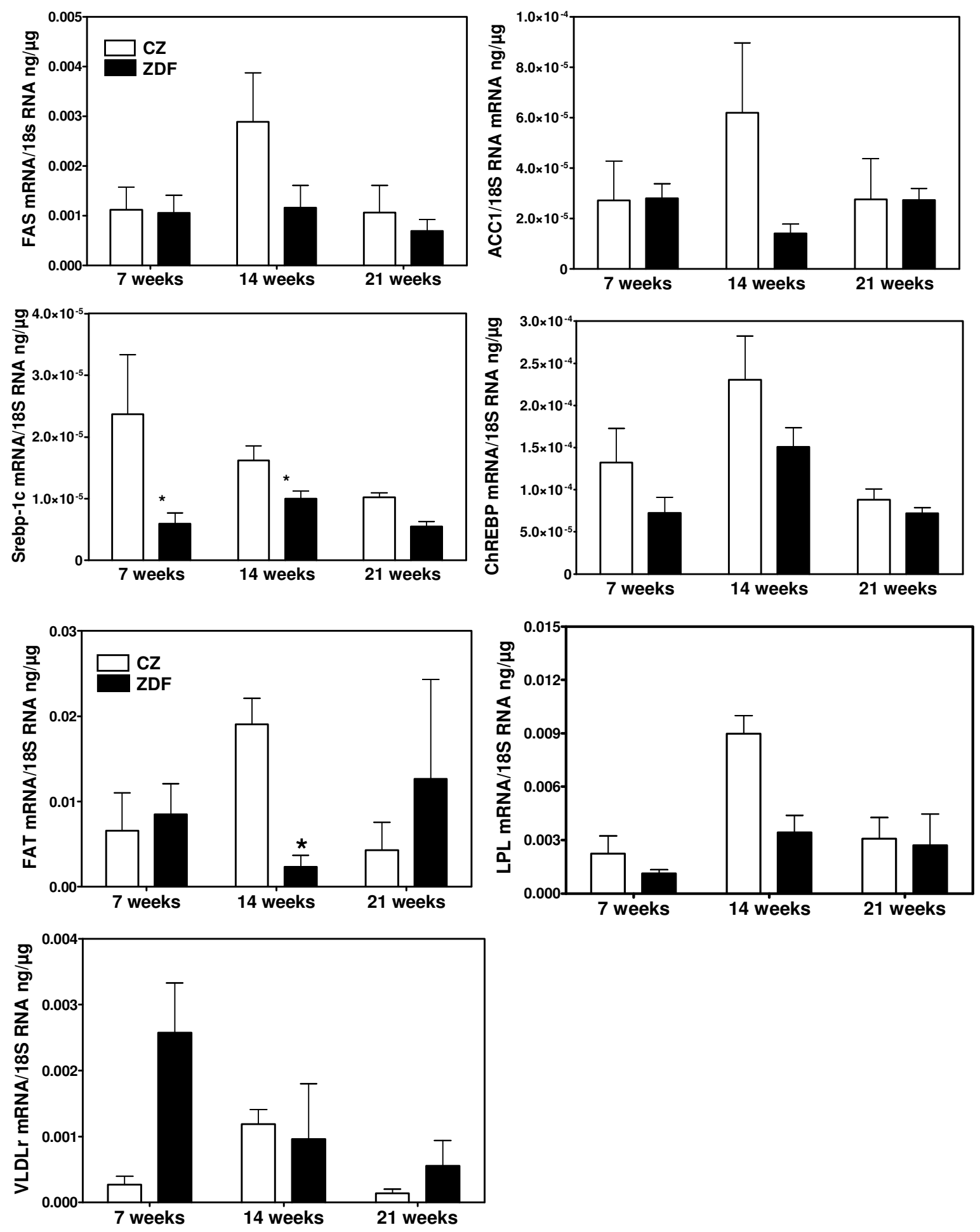

Figure I

mRNA concentrations for genes involved in fatty acid synthesis (FAS, ACCI, Srebp-I c, ChREBP) and in uptake of fatty acids from plasma lipids (FAT, LPL, VLDLr) in aortas of control (CZ) and ZDF rats studied at the age of 7,14 and 21 weeks. ${ }^{*} p<0.05$, ${ }^{*} p<0.01$ vs the corresponding value of control rats. 

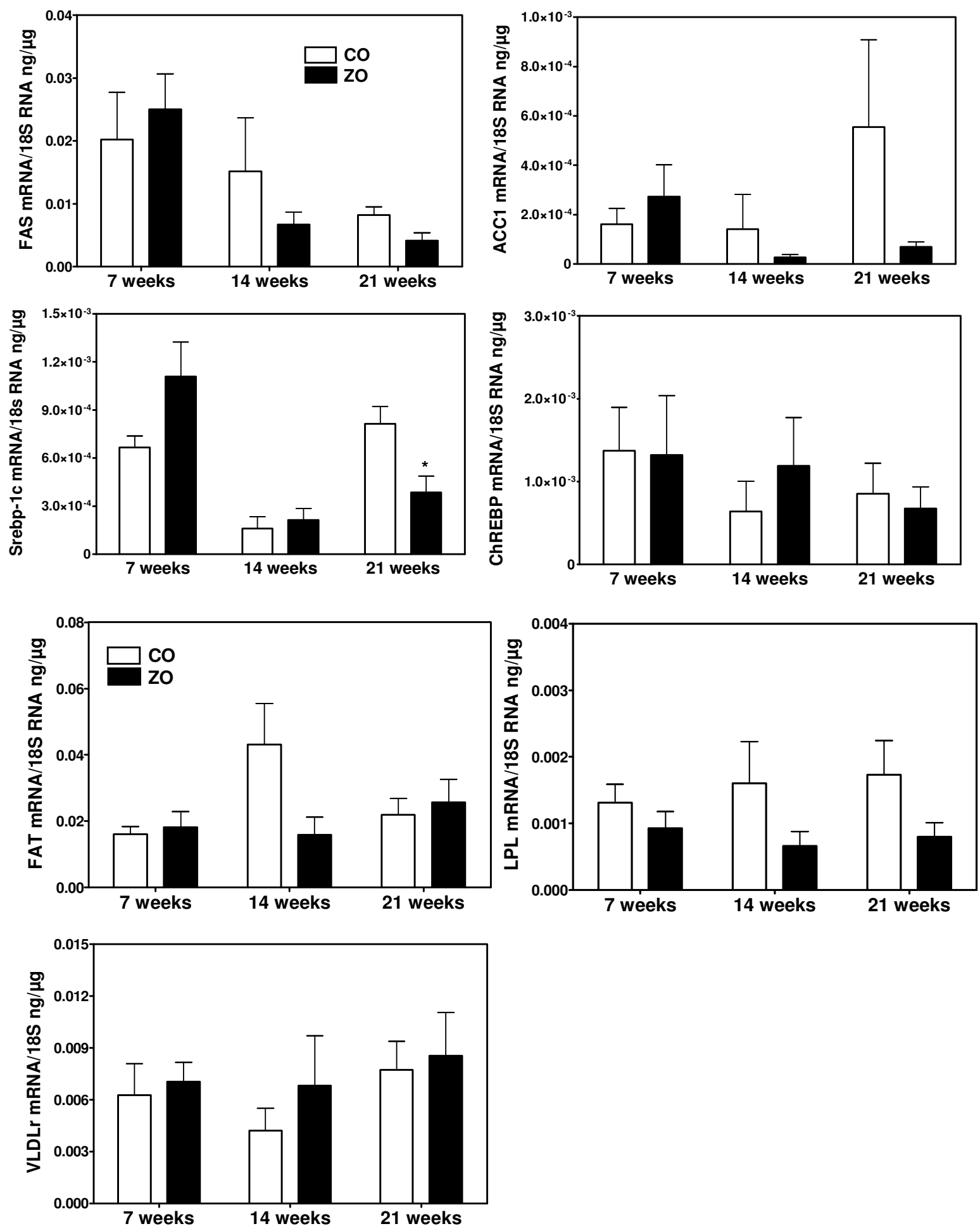

Figure 2

mRNA concentrations for genes involved in fatty acid synthesis (FAS, ACCI, Srebp-I c, ChREBP) and in uptake of fatty acids from plasma lipids (FAT, LPL, VLDLr) in aortas of control (CO) and ZO rats studied at the age of 7,14 and 21 weeks. $* p<0.05$ vs the corresponding value of control rats. 

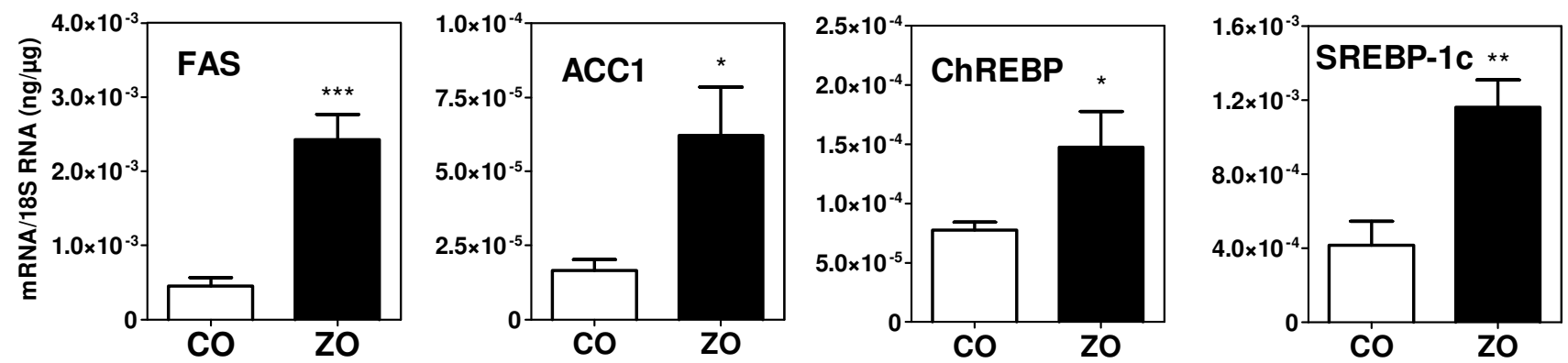

Figure 3

Expression of lipogenic genes in the liver of 14 week old control $(\mathrm{CO})$ and obese $(\mathrm{ZO})$ Zucker rats. ${ }^{*} \mathrm{p}<0.05$, ** $p<0.01$, *** $p<0.001$ vs values in CO rats.
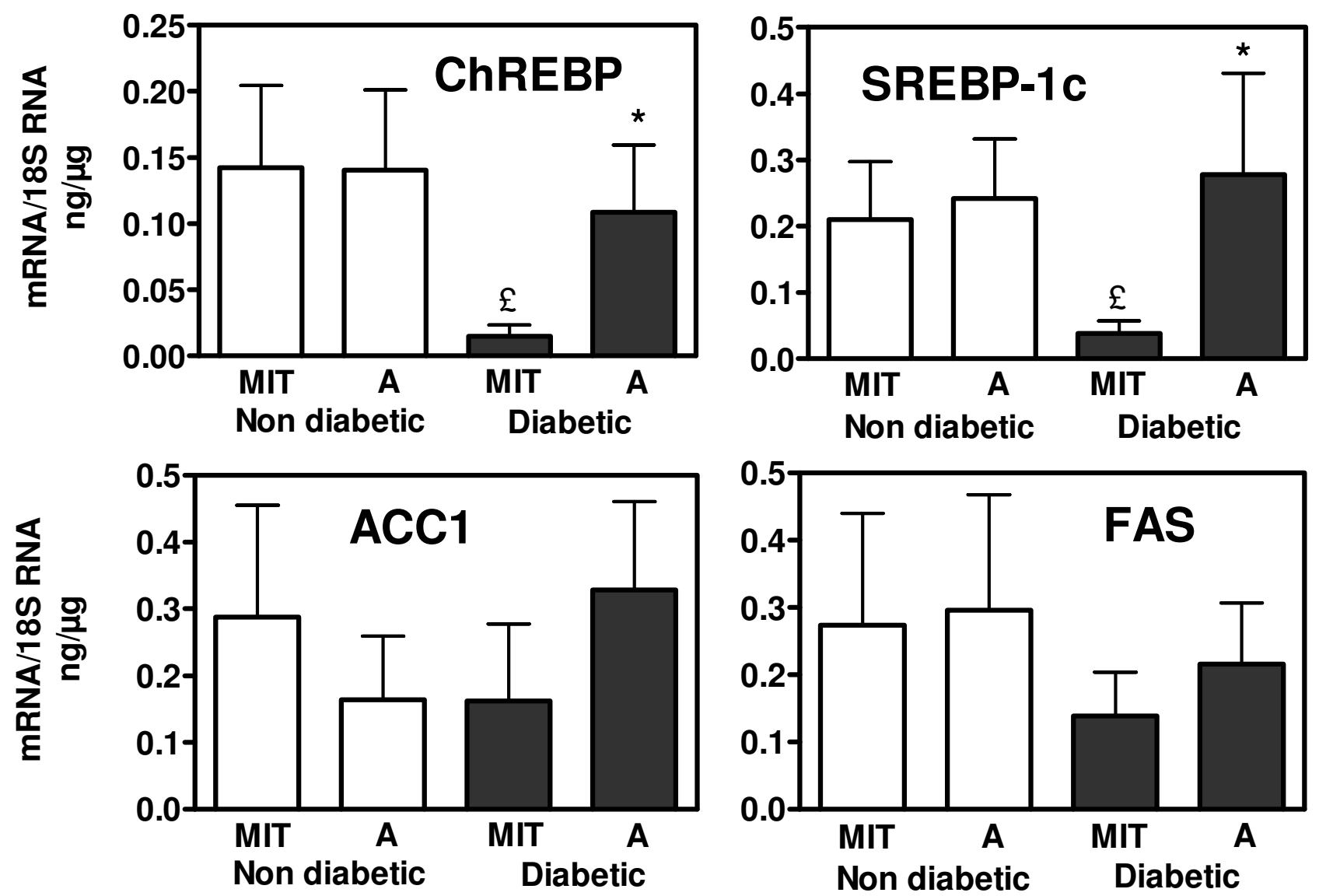

Figure 4

Concentrations of mRNA for lipogenic genes measured in human atheroma plaques (A) and in adjacent macroscopically intact tissue (MIT). Samples were collected during carotid endarterectomy in diabetic $(n=6)$ or non diabetic $(n=6)$ subjects. ${ }^{*} p<0.05$ vs values in the MIT of the same subjects; $\ell_{p}<0.05$ vs the corresponding value of non diabetic subjects. 

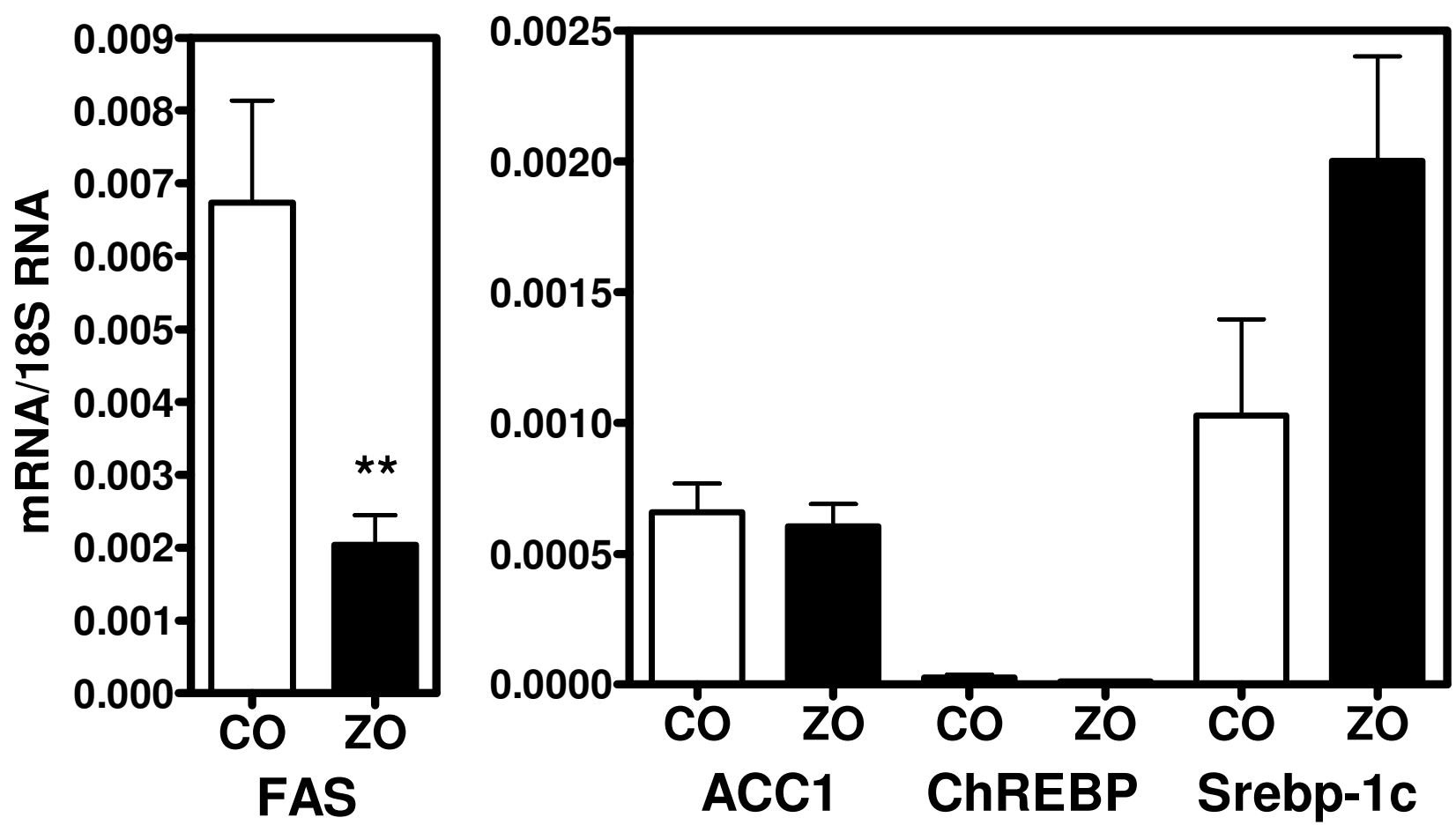

Figure 5

Lipogenic mRNA concentrations measured in the basal state in cultured VSMC obtained from aortas of Zucker obese (ZO) and control $(\mathrm{CO})$ rats. ${ }^{* *} \mathrm{p}<0.0 \mathrm{I}$ vs the value of controls.

tent (from $113 \pm 12$ to $277 \pm 23 \mu \mathrm{g} / 10^{6}$ cells, $\mathrm{p}<0.01$ ) Figure 10 shows that TO901317 increased indeed the mRNA concentrations of Srebp-1c, FAS and ACC1 while PCN had no effects. Paxillin stimulated the expression of Srebp-1c and FAS but had no effect on ACC1. In addition, TO90137 increased largely the contribution of de novo lipogenesis to cell TG content, expressed as percent $(6.8 \pm$ 0.8 vs $2.7 \pm 0.7 \%, \mathrm{p}<0.01)$ or absolute value $(18.9 \pm 3.0$ vs $2.8 \pm 0.5 \mu \mathrm{g} / 10^{6}$ cells, $\mathrm{p}<0.01$, figure 8$)$ while $\mathrm{PCN}$ had no effect (absolute lipogenesis: $4.0 \pm 1.1 \mu \mathrm{g} / 10^{6}$ cells). Taken all together these results show that the effects of TO901317 on lipogenesis are indeed mediated through activation of LXR while PXR activation has no stimulatory effect on lipogenic genes expression or on lipogenic activity in VSMC. In addition, TO901317 and paxillin had a moderate effect on the expression of FAT while PCN had no consistent action (data not shown). Since these in vitro results confirmed that LXR agonists stimulate the expression of lipogenic genes in VSMC we tested whether this action was detectable in arterial walls in vivo. Administration to mice of GW3965, a LXR agonist without action on PXR [27], increased as expected hepatic TG content (7.35 \pm 1.31 vs $2.34 \pm 0.56 \mu \mathrm{g} / \mathrm{mg}$ liver $\mathrm{p}<0.01)$ and the expression of FAS and ACC1 in liver (figure 11). However SREBP-1c expression was unchanged and the increase in the mRNA level of ChREBP, considered as a target of LXR [41] was of borderline significance $(\mathrm{p}=0.09)$. Liver FAT and FATP mRNA levels were not increased (data not shown). Plasma TG levels were not increased by GW3965, in agreement with previous data $[27,42,43]$ showing that this specific LXR agonist has no significant or only a weak hypertriglyceridemic action. TG content in aortas was indeed increased by GW3965 (34.7 \pm 7.5 vs $16.7 \pm 2.4 \mu \mathrm{g} /$ mg tissue $\mathrm{p}<0.05)$ but without increase in the expression of lipogenic genes (figure 11). FAT mRNA was not increased either but FATP expression was stimulated ( $\mathrm{p}<$ 0.01) suggesting that the rise in TG content could be related to an increased uptake of fatty acids.

\section{Discussion}

The present results confirm that the TG content of aortas increases with age [13]. They show that this content is also increased in two experimental models of insulin-resistance and diabetes. The presence in these pathological situations of excessive TG accumulation in non-adipose tissues, previously reported in liver $[35,44]$, skeletal muscle $[45,46]$, endocrine pancreas [47] and heart [48,49], is thus extended to arterial wall. Our data also extend the previous finding that lipogenic genes are expressed in arterial wall and VSMC [13] by showing that ACC1 and 

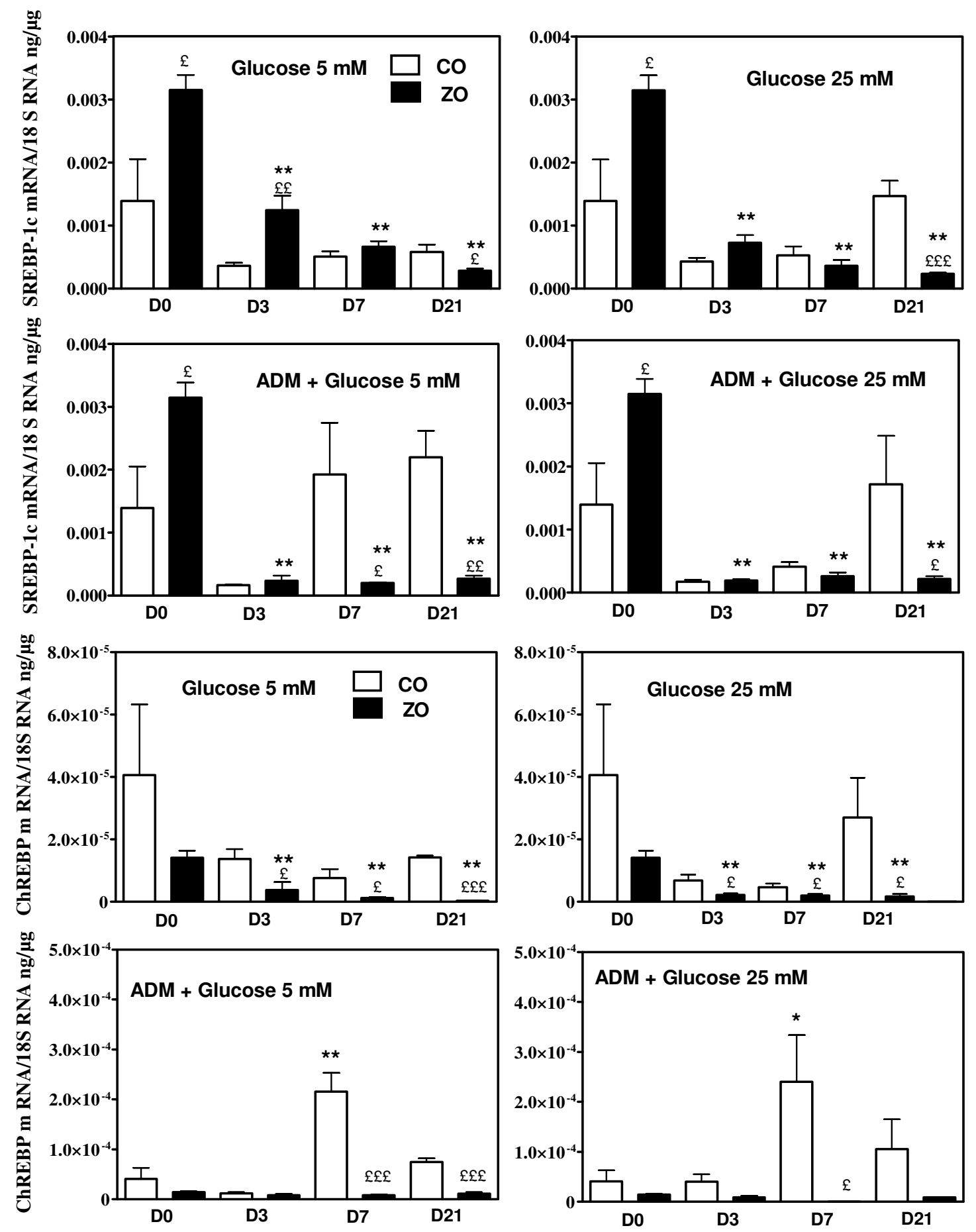

Figure 6

Srebp-I $\mathrm{c}$ and ChREBP mRNA concentrations in cultured VSMC of Zucker obese (ZO) and control (CO) rats. Concentrations were measured in the basal state (D0, glucose $5 \mathrm{mM})$ and after 3,7 and 21 days of culture (D3, D7, D2I) in basal conditions (glucose $5 \mathrm{mM}$ ), in presence of raised glucose concentration $(25 \mathrm{mM})$ or in the presence of adipogenic differentiation medium (ADM) without or with raised glucose concentrations. ${ }^{*} p<0.05$, ${ }^{*} p<0.0$ I vs the value observed at T0; $t$ $p<0.05, £ £ p<0.01, \pm £ £ p<0.00 I$ vs the corresponding value of VSMC of control rats. 

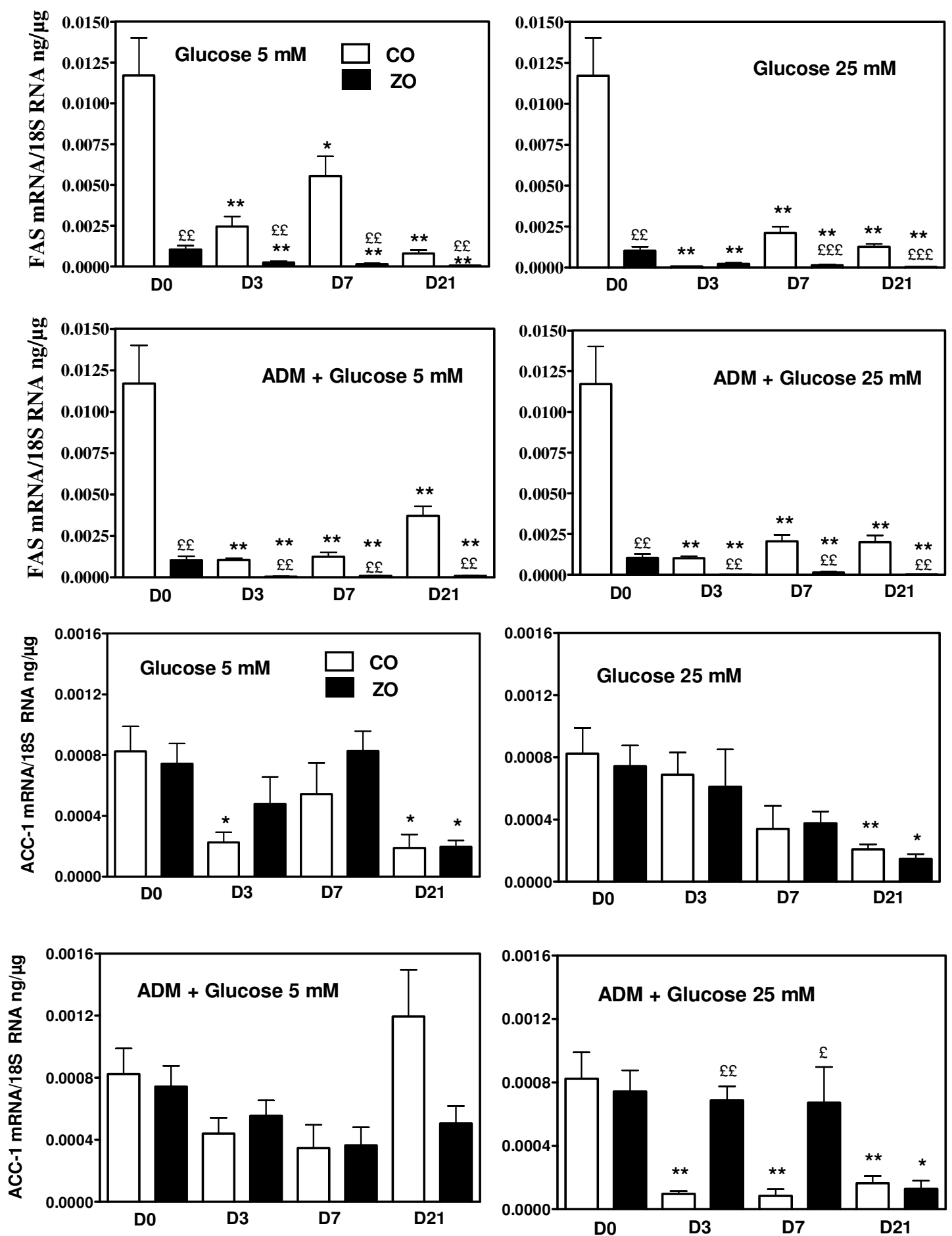

\section{Figure 7}

FAS and ACCI mRNA concentrations in cultured VSMC of Zucker obese (ZO) and control (CO) rats. Concentrations were measured in the basal state (D0, glucose $5 \mathrm{mM}$ ) and after 3,7 and 21 days of culture (D3, D7, D2 I) in basal conditions (glucose $5 \mathrm{mM}$ ), in presence of raised glucose concentration $(25 \mathrm{mM})$ or in the presence of adipogenic differentiation medium (ADM) without or with raised glucose concentrations. * $p<0.05$, ** $p<0.0$ I vs the value observed at T0; $\_p<0.05$, $£ £ p<0.01, £ £ \in \mathrm{p}<0.001$ vs the corresponding value of VSMC of control rats. 

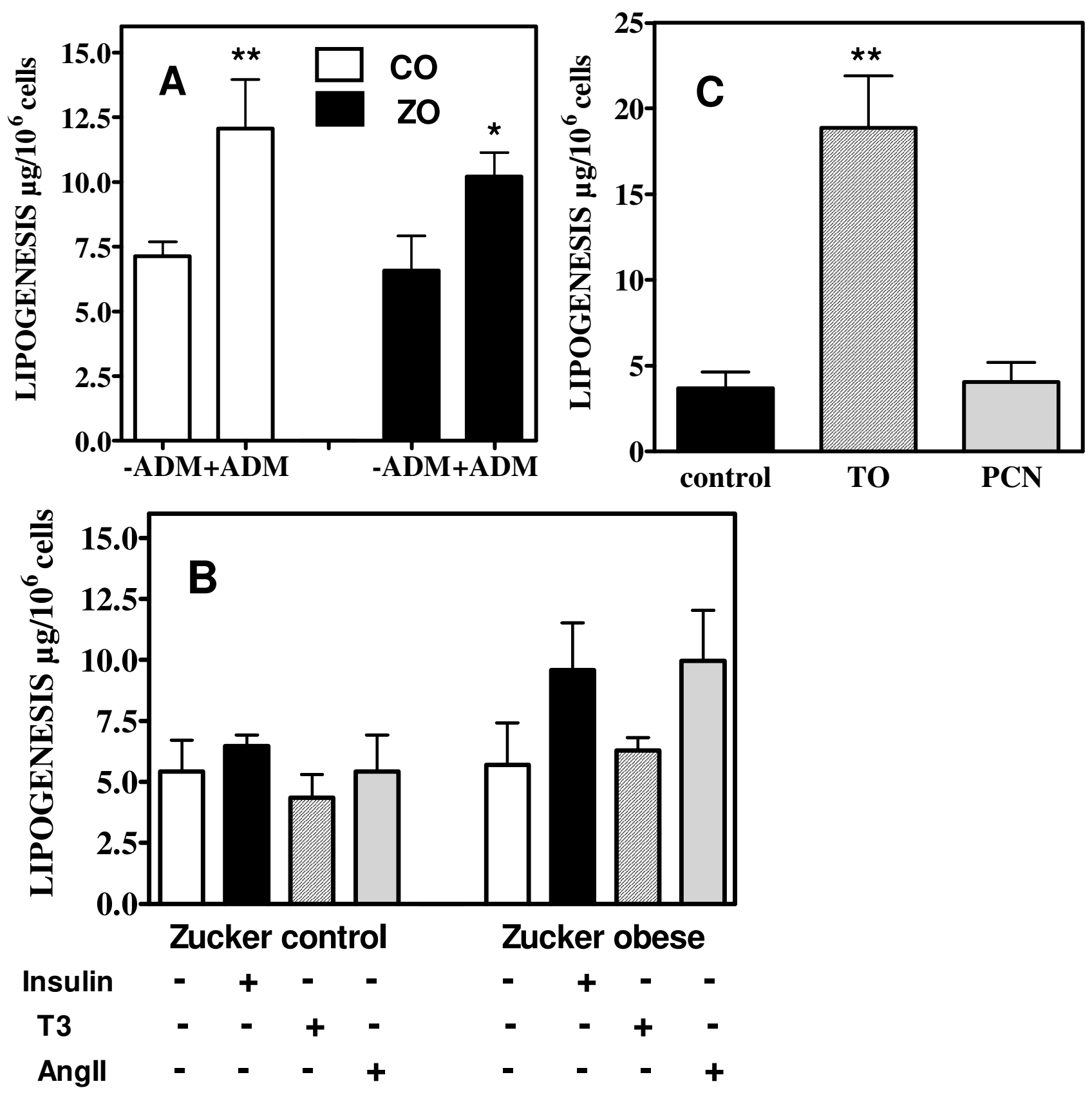

Figure 8

Activity of the lipogenic pathway (expressed as contribution to the cellular TG pool) measured in VSMC of control and obese Zucker rats cultured in the presence or absence of adipogenic medium (ADM) (panel A), in the presence or absence of insulin, trioiodothyronine (T3) or angiotensin II (AngII) (panel B) and in VSMC of control Zucker rats cultured without (control) or with TO90I3 I 7 (TO) or PCN (panel C). ${ }^{*} p<0.05$, ${ }^{*} * p<0.01$ vs the corresponding control situation. 

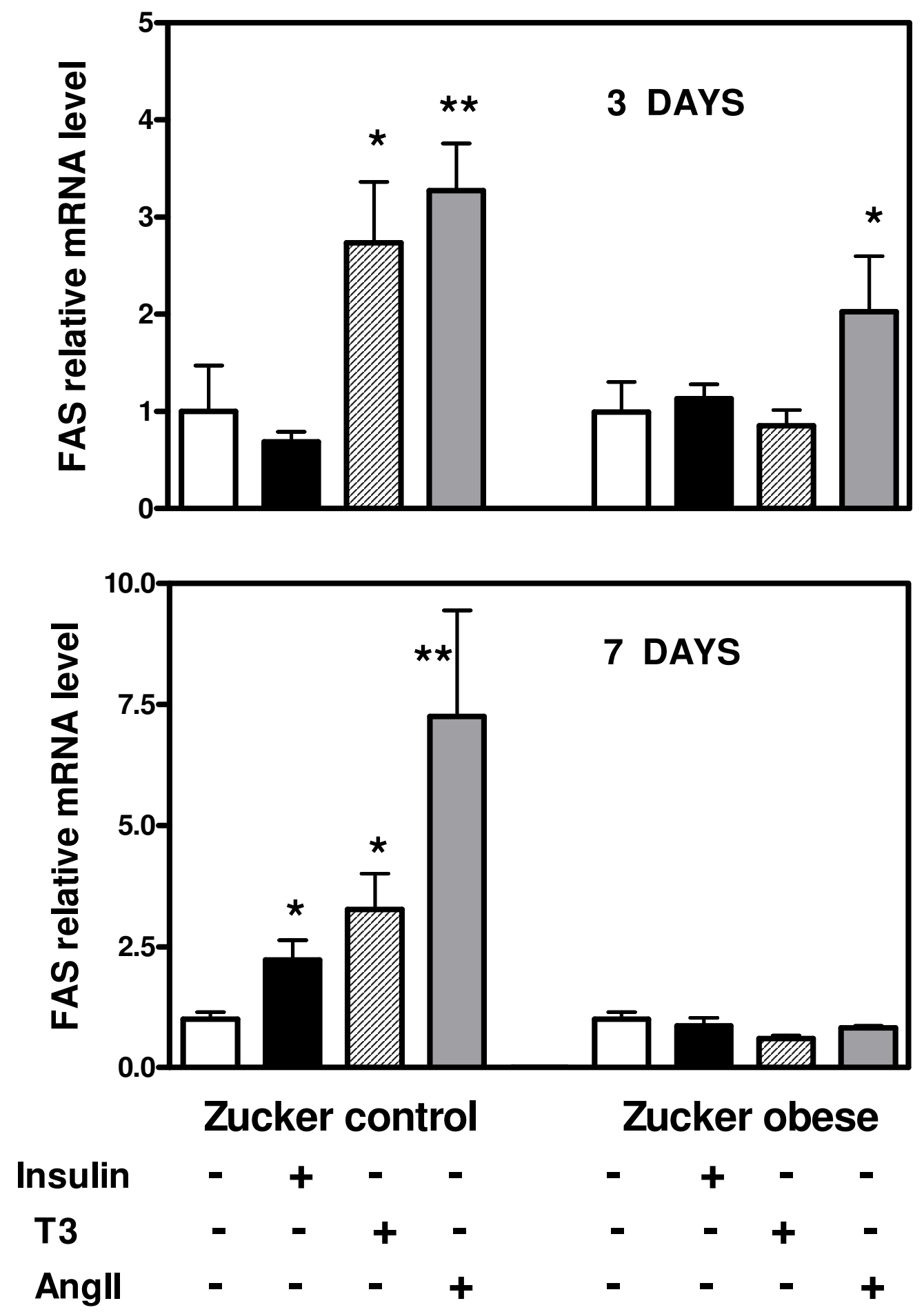

Figure 9

FAS mRNA concentrations in VSMC of Zucker obese and control rats after three or seven days of culture in the absence (-) or presence (+) of insulin, T3 or angiotensin II. ${ }^{*} \mathrm{p}<0.05,{ }^{* *} \mathrm{p}<0.0 \mathrm{I}$ vs the corresponding value in the absence $(-)$ of the tested molecule. 

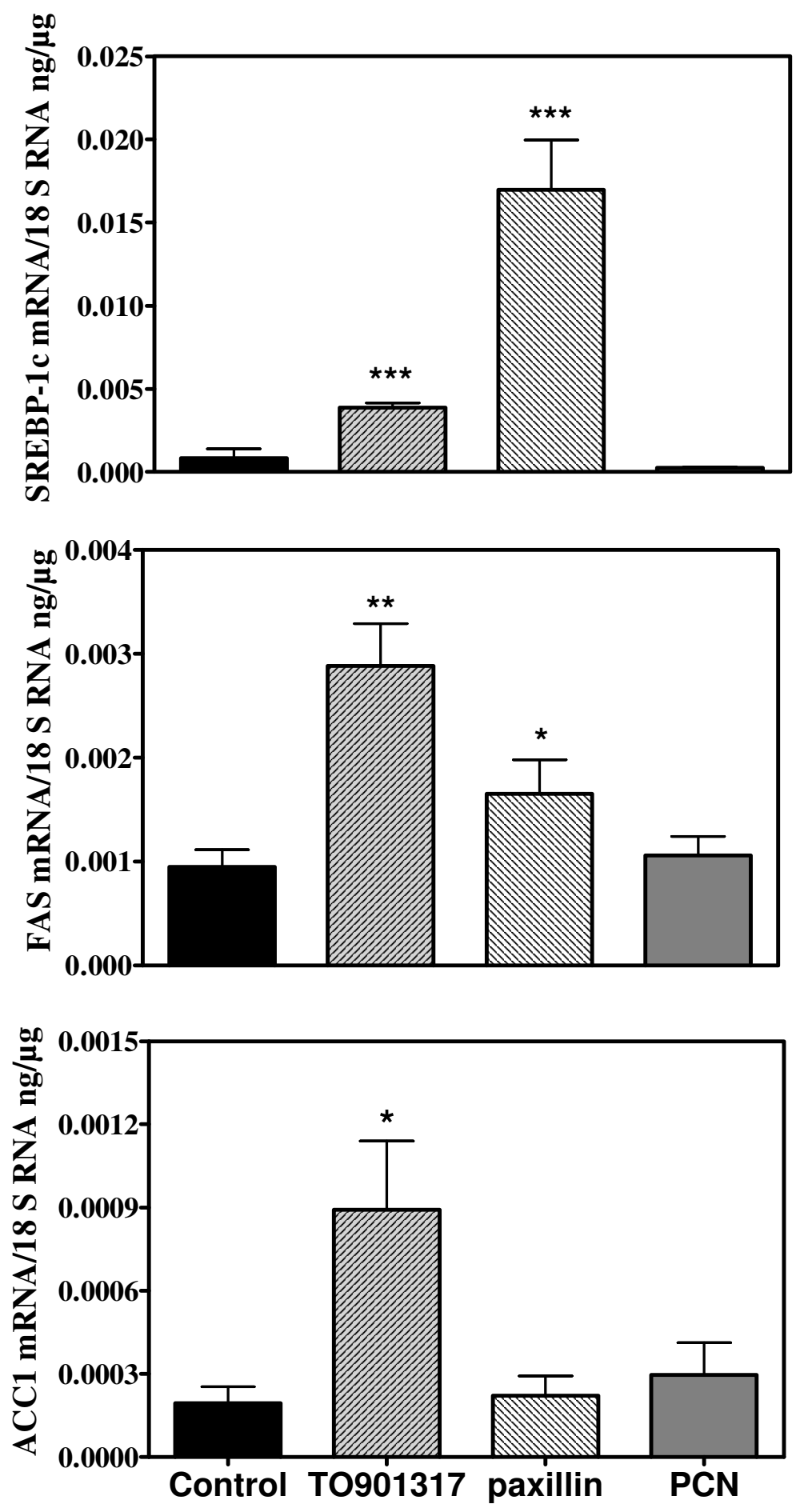

Figure 10

Response of lipogenic genes to agonists of PXR (PCN), LXR (paxillin) and to a dual PXR and LXR agonist (TO90 I 3 I 7). mRNA concentrations (VSMC of control rats) were measured after three days of culture (glucose $5 \mathrm{mM}$, no ADM) in the absence (control) or presence of the various agonists. ${ }^{*} p<0.05$, ${ }^{* *} p<0.01, *^{* *} p<$ 0.001 vs control. 

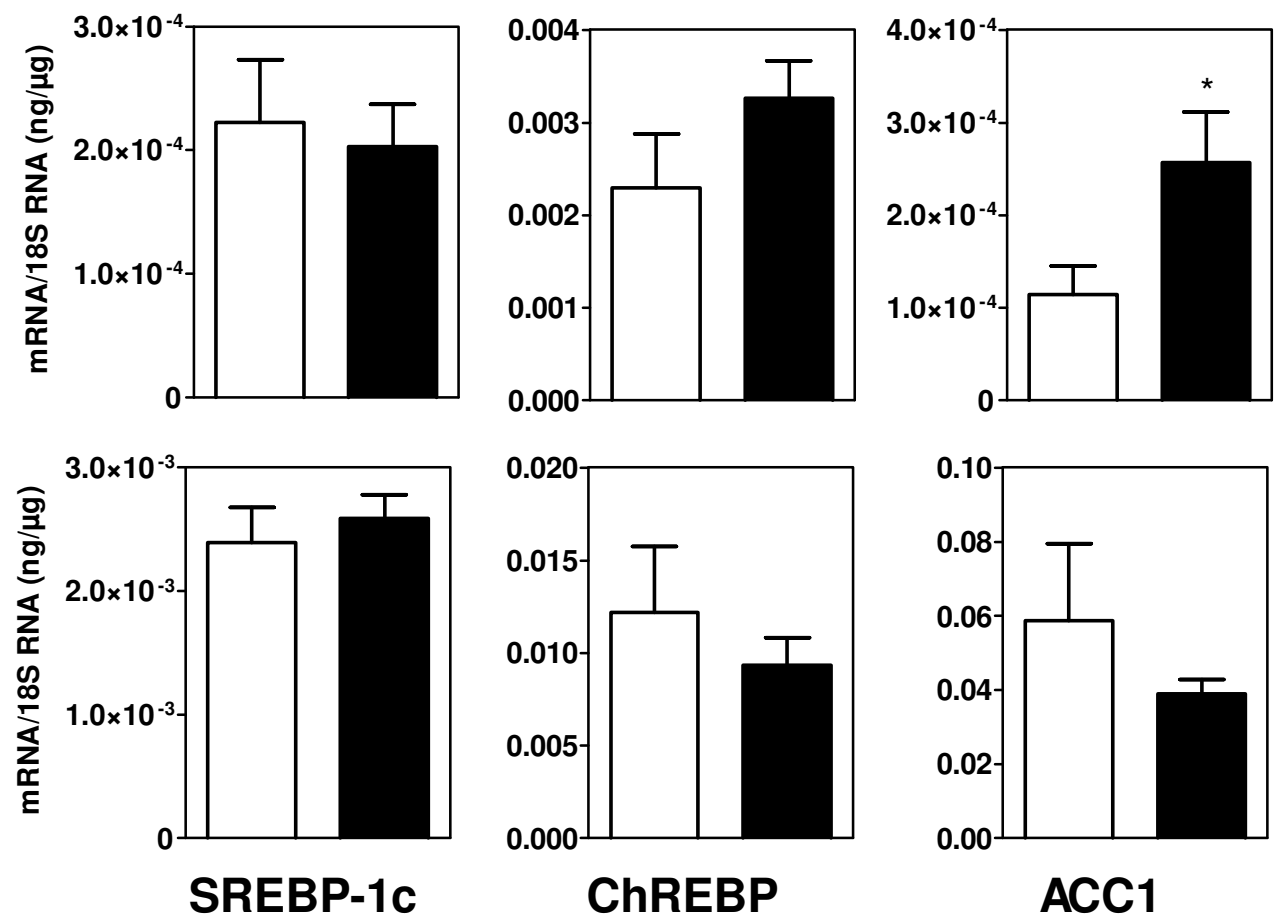
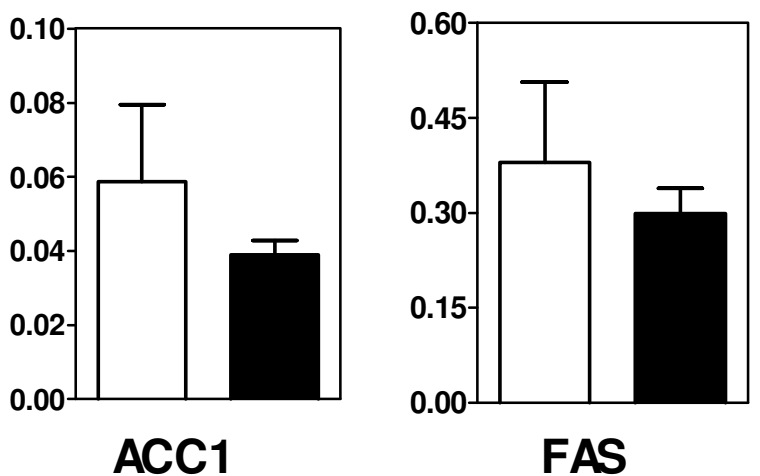

Figure I I

Expression of lipogenic genes in liver (upper panel) and aortas (lower panel) of mice after a three days administration of GW3965 (black columns) or vehicle alone (control, white columns). ${ }^{*} p<0.05$ vs the control group.

ChREBP, the transcription factor mediating the stimulatory effects of glucose on lipogenic genes expression, are also expressed in this tissue and these cells.

Our first aim was to determine whether modifications of the in situ expression of lipogenic genes could contribute to physiological (aging) or pathological (insulin-resistance and diabetes) increases in arterial wall TG content. We found no increase with age or insulin-resistance in any of the lipogenic mRNA measured. Although we determined only mRNA concentrations, it is thus unlikely that enhanced lipogenesis contributed to the increased TG content. We also found no increase with age or insulinresistance in the expression of genes involved in the uptake of plasma NEFA or of fatty acids of TG-rich lipoproteins. Altogether, these results suggest that the increased TG content of arterial wall observed in insulinresistance and diabetes result mainly from the increased concentration and availability of circulating lipid substrates for uptake by cells of the arterial wall.

The lack of increase of lipogenic mRNA levels in aortas of insulin-resistant or diabetic Zucker rats strongly suggests in addition that in these situations lipogenesis is resistant to the actions of insulin and glucose. Interestingly, when measuring lipogenic mRNA concentrations in carotid endarterectomy samples from diabetic and non-diabetic patients, we found that theses concentrations were decreased in macroscopically intact arterial tissue of diabetic patients and comparable in atheroma plaques of diabetic and non-diabetic patients, supporting also the presence of resistance to insulin of arterial lipogenesis in human diabetes. Data obtained in cultured VSMC of ZO rats also support this resistance. In basal conditions, FAS expression was decreased. More importantly, only cells of control rats had a moderate response of lipogenic genes to glucose and adipogenic factors in combination or alone. VSMC from ZO rats did not respond and had mRNA values largely lower than cells from control rats. Lastly the stimulatory action of ADM on the activity of the lipogenic pathway was decreased in VSMC from ZO rats. Taken altogether, theses results obtained in human beings, in rats and in cultured VSMC strongly support the idea that the insulin-resistance of arterial wall previously described [9] involves the lipogenic pathway. This resistance could be more general since the stimulatory effects of T3 and AngII on FAS expression were also reduced or abolished in cells from $\mathrm{ZO}$ rats. 
The status of arterial wall lipogenesis in situations of insulin-resistance is thus comparable to the one observed in skeletal muscle [26] and adipose tissue [50]: decreased basal expression and resistance to the action of insulin. This repression of lipogenesis contrasts sharply with its hepatic overexpression in both experimental models of insulin-resistance $[35,44]$ and human subjects with obesity and insulin-resistance $[38,50]$. In addition, this overexpression of liver lipogenic genes contributes to the excessive hepatic accumulation of TG found in these situations $[25,38,51,52]$. The reasons behind this discrepancy in the status of lipogenesis between liver on one hand and adipose tissue, skeletal muscle and VSMC on the other remain unclear. Whatever the reasons for this discrepancy, the increased lipid accumulation found in arterial wall of insulin-resistant and diabetic rats could contribute to its insulin-resistance [9]

Lastly, we confirm the previously described stimulatory effect of TO901317 on expression of lipogenic genes [13] in VSMC. We show in addition that this is accompanied by a clear increase in the activity of the lipogenic pathway and is mediated though activation of the nuclear receptor LXR since this effect is reproduced by a specific LXR agonist but not by a selective PXR agonist. LXR agonists have been proposed as a possible treatment of atheroma. Indeed they reduce the development of atheroma in mice model [53] through stimulation of cellular cholesterol efflux and reverse transport [54], and possibly also through some anti-inflammatory action [55]. A drawback with compounds such as TO931317 is the rise in plasma TG concentrations. This could be solved by using other, more specific, LXR agonists such as GW3965. Indeed, in agreement with previous reports [27,42,43], GW3965 did not increase plasma TG levels in mice. However, despite the lack of significant increase of the expression of lipogenic genes in arterial wall, GW3965 increased in the present report arterial TG content. The possible deleterious effects on a long term basis of this increase in arterial lipids accumulation should be kept in mind. Clarifying the consequences of such direct actions of LXR agonists on arterial wall on the development of atheroma will require further studies.

In summary, we found that arterial wall TG content increases with age and in situations of insulino-resistance and type 2 diabetes. Lipogenic genes are expressed in normal and pathological (atheroma plaques) arterial wall as well as in VSMC. Their expression is stimulated in vitro by glucose, ADM and LXR agonists. However, these expressions are not increased during insulin-resistance and diabetes and resist to the in vitro actions of glucose and ADM. Therefore, it is unlikely that in situ (arterial wall) lipogenesis contributes to lipid accumulation in arterial wall dur- ing insulin-resistance and diabetes and thus to the increased risk of atheroma observed in these situations.

\section{Competing interests}

The authors declare that they have no competing interests.

\section{Authors' contributions}

$\mathrm{NH}$ realized part of the in vivo protocols and most of the in vitro studies and measurements of mRNA, and drafted the paper. FF was involved in vitro studies and set up most of mRNA quantifications. SN participated in the in vitro studies and the in vivo study in mice. PdC participated to in vivo protocols in rats and mice. PF and GB were responsible for the studies in humans. SAB and MB conceived the study, were responsible for the general design and coordination and drafted the paper. All authors approved the final manuscript.

\section{Acknowledgements}

This work was supported in part by a grant from the Fondation de France and a joint grant from the ALFEDIAM and laboratoire PZIFER

\section{References}

I. Schaffer J: Lipotoxicity: when tissues overeat. Curr Opin Lipidol 2003, I 4:28I-287.

2. Schulman G: Cellular mechanisms of insulin resistance. J Clin Invest 2000, 106:171-176.

3. Capeau J: Insulin resistance and steatosis in humans. Diabetes Metab 2008, 34:649-657.

4. Schrauwen P: High-fat diet, muscular lipotoxicity and insulin resistance. Proc Nutr Soc 2007, 66:33-4I.

5. Listenberger L, Han X, Lewis S, Cases S, Farese R, Ory D, Schaffer J: Triglyceride accumulation protects against fatty acidinduced lipotoxicity. Proc Natl Acad Sci 2003, I 00:3077-3082.

6. Yu CCY, Cline GW, Zong H, Wang Y, Bergeron R, Kim JK, Cushman SW, Cooney G], Atcheson B, White MF, Kraegen EW, Shulman GI: Mechanism by Which Fatty Acids Inhibit Insulin Activation of Insulin Receptor Substrate-I (IRS-I)-associated Phosphatidylinositol 3-Kinase Activity in Muscle. J Biol Chem 2002, 277:50230-50236.

7. Park T, Hu Y, Noh H, Drosatos K, Okajima K, Buchanan J, Tuinei J, Homma $S$, Jiang $X$, Abel $E$, et al.: Ceramide is a cardiotoxin in lipotoxic cardiomyopathy. J Lipid Res 2008, 49:2 I0 I-2 I I 2.

8. Haus J, Kashyap S, Kasumov T, Zhang R, Kelly K, De Fronzo R, Kirwan $\mathrm{J}:$ Plasma ceramides are elevated in obese subjects with type 2 diabetes and correlate with the severity of insulin resistance. Diabetes 2009, 58:337-344.

9. Jiang Z, Lin Y, Clemont A, Feener E, Hein K, Igarashi M, Yamauchi T, White $M$, King G: Characterization of the selective resistance to insulin signaling in the vasculature of obese Zucker (fa/fa) rats. J Clin Invest 1999, 104:447-457.

10. Hodroj W, Legedz L, Foudi N, Cerutti C, Bourdillon M, Feugier P, Beylot M, Randon J, Bricca G: Increased Insulin-Stimulated Expression of Arterial Angiotensinogen and Angiotensin Type I Receptor in Patients With Type 2 Diabetes Mellitus and Atheroma. Arterioscler Thromb Vasc Biol 2007, 27:525-53I.

II. Hotamisligil G, Budavari A, Murray D, Spielgelman B: Reduced tyrosine kinase activity of the insulin receptor in obesity-diabetes. Contral role of TNF alpha. J Clin Invest 1994, 94: I543-I 549.

12. Folli F, Kahn C, Hansen H, Bouchie J, Feener E: Angiotensin II inhibits insulin signaling in aortic smooth muscle cells at multiple levels. A potential role for serine phosphorylation in insulin/angiotensin II crosstalk. J Clin Invest 1997, I 00:2 I 58-2 169.

13. Davies J, Carpenter K, Challis I, Figg N, McNair R, Proudfoot D, Weissberg P, Shanahan C: Adipocytic differenciation and liver $x$ receptor pathways regulate the accumulation of triacylglycerols in human vascular smooth muscle cells. J Biol Chem 2005, 280:3911-3919. 
14. Smith $E$, Slate $E$, Chu $P$ : The lipids in raised fatty and fibrous lesions in human aorta. A comparison of the changes at different stage of development. J Atheroscler Res 1968, 8:399-4I9.

15. Smith E, Slater R: The microdissection of large atherosclerotic plaques to give morphologically and topographically defined fractions for analysis. I. the lipids in isolated fractions. Atherosclerosis 1972, 15:37-56.

16. Lada AT, Rudel LL, Clair RWS: Effects of LDL enriched with different dietary fatty acids on cholesteryl ester accumulation and turnover in THP-I macrophages. Journal of Lipid Research 2003, 44(4):770-779.

17. Adelman SJ, Glick JM, Phillips MC, Rothblat GH: Lipid composition and physical state effects on cellular cholesteryl ester clearance. Journal of Biological Chemistry 1984, 259(22): I 3844-I3850.

18. Portman O: Arterial composition and metabolism: esterified fatty acids and cholesterol. Adv Lipid Res 1970, 8:41-II4.

19. Foufelle F, Ferré P: New perspectives in the regulation of hepatic glycolytic and lipogenic genes by insulin and glucose: a role for the transcription factor sterol regulatory element binding protein- Ic. Biochem J 2002, 366:377-39 I.

20. Repa LG JJ, Ou J, Bashmakov Y, Lobaccaro JM, Shimomura I, Shan B, Brown MS, Goldstein JL, Mangelsdorf DJ: Regulation of mouse sterol regulatory element-binding protein-Ic gene (SREBPIc) by oxysterol receptors, LXRalpha and LXRbeta. Genes Dev 2000, I 4:2819-2830.

21. Kase ET, Wensaas AJ, Aas V, Hojlund K, Levin K, Thoresen GH, BeckNielsen H, Rustan AC, Gaster M: Skeletal Muscle Lipid Accumulation in Type 2 Diabetes May Involve the Liver $\times$ Receptor Pathway. Diabetes 2005, 54(4): I I08-I I I5.

22. Juvet AS LK, Schuster GU, Dalen KT, Tobin KA, Hollung K, Haugen F, Jacinto S, Ulven SM, Bamberg K, Gustafsson JA, Nebb HI: On the role of liver $\times$ receptors in lipid accumulation in adipocytes. Mol Endocrinol 2003, 17:172-182.

23. Cozzone D, Debard C, Dif N, Ricard N, Disse E, Vouillarmet J, Rabasa-Lhoret R, Laville M, Pruneau D, Rieusset J, et al:: Activation of liver $x$ receptors promotes lipid accumulation but does not alter insulin action in human skeletal muscle cells. Diabetologia 2006, 49(5):990-999.

24. Uyeda $\mathrm{K}$, Yamashita $\mathrm{H}$, Kawaguchi T: Carbohydrate responsive element-binding protein (ChREBP): a key regulator of glucose metabolism and fat storage. Biochemical Pharmacology 2002, 63:13476-13478

25. Dentin R, Pegorier J, Benhamed F, Foufelle F, Ferré P, Fauveau V, Magnuson $M$, Girard J, Postic $C$ : Hepatic glucokinase is required for the synergistic action of ChREBP and SREBP-I on glycolytic and lipogenic gene expression. J Biol Chem 2004, 279:203।4-20326

26. Ducluzeau P-H, Perretti N, Laville M, Andreelli F, Vega N, Riou J-P, Vidal H: Regulation by Insulin of Gene Expression in Human Skeletal Muscle and Adipose Tissue: Evidence for Specific Defects in Type 2 Diabetes. Diabetes 200I, 50(5): I |34-| | 42.

27. Mitro N, Vargas L, Romeo R, Koder A, Saez E: T0901317 is a potent PXR ligand: Implications for the biology ascribed to LXR. FEBS Letters 2007, 58 I(9): I72I-I726.

28. Moreau A, Téruel C, Beylot M, Albalea $V$, Tamasi $V$, Umbdenstock $T$, Parmentier Y, Sa-Cunha A, Suc B, Fabre J, et al:: A novel pregnane $x$ receptor and SI4-mediated lipogenic pathway in human hepatocyte. Hepatology 2009:2068-2079.

29. Hagedorn KA, Cooke C-L, Falck JR, Mitchell BF, Davidge ST: Regulation of Vascular Tone During Pregnancy: A Novel Role for the Pregnane $\times$ Receptor. Hypertension 2007, 49(2):328-333.

30. Forcheron F, Legedz L, Chinetti G, Feugier P, Letexier D, Bricca G, Beylot M: Genes of cholesterol metabolism in human atheroma: overexpression of perilipin and genes promoting cholesterol storage and repression of ABCAI expression. Arterioscler Thromb Vasc Biol 2005, 25: I7II-1717.

31. Ran J, Hirano T, Adachi M: Chronic angiotensin II infusion increases plasma triglyceride level by stimulating hepatic triglyceride production in rats. Am J Physiol 2004, 287:E955-E96I.

32. Jones B, Stanbridge M, Moustaid N: Angiotensin II increases lipogenesis in 3T3-LI and human adipose cells. Endocrinology 1997, i38: $1512-1519$

33. Bramlett KS, Houck KA, Borchert KM, Dowless MS, Kulanthaivel P, Zhang Y, Beyer TP, Schmidt R, Thomas JS, Michael LF, et al.: A Natural Product Ligand of the Oxysterol Receptor, Liver $x$
Receptor. Journal of Pharmacology And Experimental Therapeutics 2003, 307(I):29I-296.

34. Forcheron F, Cachefo A, Thevenon S, Pinteur C, Beylot M: Mechanisms of the triglyceride and cholesterol-lowering effect of fenofibrate in hyperlipidemic type 2 diabetic patients. Diabetes 2002, 5 I:3486-349I.

35. Forcheron F, Abdallah P, Basset A, Del Carmine P, Haffar G, Beylot $M$ : Non-Alcoholic hepatic steatosis in Zucker diabetic rats: spontaneous evolution and effects of metformin and fenofibrate. Obesity 2009:1381-1389.

36. Yang D, Diraison F, Beylot M, Brunengraber Z, Samols M, Brunengraber $\mathrm{H}$ : assay of low deuterium enrichment of water by isotopic exchange with [U-13C]acetone and gas chromatography mass spectrometry. Anal Biochem 1998, 258:3|5-32|.

37. Diraison F, Pachiaudi C, Beylot M: Measuring lipogenesis and cholesterol synthesis in humans with deuterated water: use of simple gas chromatography mass spectrometry techniques. J Mass Spectrom 1997, 32:8I-86.

38. Diraison F, Beylot M, Moulin P: Contribution of hepatic de novo lipogenesis and reesterification of plasma NEFA to plasma triglyceride synthesis during non-alcoholic fatty liver disease. Diabetes \& Metabolism 2003, 29: I-8.

39. Suh Y, Kim Y, Bang J, Choi K, Lee J, Kim W, Oh T, AN S, Jung M: Analysis of gene expression profiles in insulin-sensitive tissues from pre-diabetic and diabetic Zucker diabetic fatty rats. J Mol Endocrinol 2005, 34:299-3I5.

40. Kakuma T, Lee Y, Higa M, Wanf Z, Pan W, Shimomura I, Unger R: Leptin, troglitazone, and the expression of sterol regulatory element binding proteins in liver and pancreatic islets. Proc Natl Aca Sci 2000, 97:8536-854I.

4I. Cha JY, Repa JJ: The Liver $\times$ Receptor (LXR) and Hepatic Lipogenesis: the carbohydrate-response element binding protein is a target gene of LXR. J Biol Chem 2007, 282(I):743-75I.

42. Miao B, Zondlo S, Gibbs S, Cromley D, Hosagrahara VP, Kirchgessner TG, Billheimer J, Mukherjee R: Raising HDL cholesterol without inducing hepatic steatosis and hypertriglyceridemia by a selective LXR modulator. Journal of Lipid Research 2004, 45(8): $1410-14 \mid 7$

43. Joseph SB, McKilligin E, Pei L, Watson MA, Collins AR, Laffitte BA, Chen M, Noh G, Goodman J, Hagger GN, et al.: Synthetic LXR ligand inhibits the development of atherosclerosis in mice. Proceedings of the National Academy of Sciences of the United States of America 2002, 99( I I):7604-7609.

44. Lin H, Yang S, Chuckabee C, Kuhajda F, Ronnet G, Dielh A: Metformin reverses fatty liver disease in obese, leptin-deficient mice. Nature Med 2000, 6:998-1003.

45. Laybutt D, SchmitzPeiffer C, Saha K, Ruderman N, Biden T, Kraegen $E$ : Muscle lipid accumulation and protein kinase $C$ activation in the insulin-resistant chronically glucose-infused rat. $\mathrm{Am}$ Physiol 1999, 277:EI070-EI076.

46. Pan D, Lillioja S, Kriketos A, Milner M, Baur L, Bogardus C, Jenkins A, Storlien L: Skeletal muscle triglyceride levels are inversely related to insulin action. Diabetes 1997, 46:983-988.

47. Poitout V, Robertson RP: Glucolipotoxicity: Fuel Excess and beta-Cell Dysfunction. Endocrine Reviews 2008, 29(3):35I-366.

48. Forcheron F, Basset A, Abdallah P, Del Carmine P, Gadot N, Beylot $M$ : Diabetic cardiomyopathy: effects of fenofibrate and meformin in an experimental model - the Zucker diabetic rat. Cardiovascular Diabetology 2009, 8(I): 16 .

49. Zhou Y, Graybirn P, Karim A, Scimabukuro M, Higa M, Baetens D, Orci L, Unger R: Lipotoxic heart disease in obese rats: implications for human obesity. Proc Natl Acad Sci 2000, 97: 1784-1789.

50. Diraison F, Dusserre E, Vidal H, Sothier M, Beylot M: Increased hepatic lipogenesis but decreased expression of lipogenic gene in adipose tissue in human obesity. AmJ Physiol 2002, 282:E46-5।.

51. Donnelly K, Smith C, Schwarzenberg S, Jessurun J, Boldt M, Parks E: Sources of fatty acids stored in liver and secreted via lipoproteins in patients with nonalocoholic fatty liver disease. J Clin Invest 2005, I I 5: |343-| 35 I.

52. Denechaud DR PD, Girard J, Postic C: Role of ChREBP in hepatic steatosis and insulin resistance. FEBS Lett 2008, 582:68-73.

53. Joseph ME SB, Pei L, Watson MA, Collins AR, Laffitte BA, Chen M, Noh G, Goodman J, Hagger GN, Tran J, Tippin TK, Wang X, Lusis AJ, Hsueh WA, Law RE, Collins JL, Willson TM, Tontonoz P: Synthetic 
LXR ligand inhibits the development of atherosclerosis in mice. Proc Natl Acad Sci USA 2002, 99:7604-7609.

54. Naik SU, Wang X, Da Silva JS, Jaye M, Macphee $\mathrm{CH}$, Reilly MP, Billheimer JT, Rothblat GH, Rader DJ: Pharmacological Activation of Liver $\times$ Receptors Promotes Reverse Cholesterol Transport In Vivo. Circulation 2006, I I 3:90-97.

55. Hong C, Tontonoz P: Coordination of inflammation and metabolism by PPAR and LXR nuclear receptors. Curr Opin Genet Dev 2008, I 8:46I-467.

Publish with Biomed Central and every scientist can read your work free of charge

"BioMed Central will be the most significant development for disseminating the results of biomedical research in our lifetime. "

Sir Paul Nurse, Cancer Research UK

Your research papers will be:

- available free of charge to the entire biomedical community

- peer reviewed and published immediately upon acceptance

- cited in PubMed and archived on PubMed Central

- yours - you keep the copyright

Submit your manuscript here:

http://www.biomedcentral.com/info/publishing_adv.asp
BioMedcentral 